\title{
Types, methods, techniques, and applications for Microencapsulated Phase Change Materials (MPCM): A review
}

\author{
Jessica Giro-Paloma ${ }^{1, a}$; Mònica Martínez ${ }^{2, a}$; Luisa F. Cabeza ${ }^{3, b}$; A. Inés Fernández ${ }^{4, a, *}$ \\ aDepartament de Ciència dels Materials i Enginyeria Metal-lúrgica, Universitat de Barcelona, Martí i Franqués 1-11, 08028, \\ Barcelona, Spain, Phone: 34-934021316, Fax: 34-93.4035438 \\ ${ }^{\text {b} G R E A ~ I n n o v a c i o ́ ~ C o n c u r r e n t . ~ E d i f i c i ~ C R E A . ~ U n i v e r s i t a t ~ d e ~ L l e i d a . ~ C / ~ P e r e ~ d e ~ C a b r e r a ~ s / n, ~ 25001-L l e i d a ~(S p a i n), ~ P h o n e: ~} 34-$ \\ 973003576, Fax: 34-973003575 \\ 1essicagiro@ub.edu; ${ }^{2}$ monicamartinez@ub.edu; $;{ }^{3}$ lcabeza@diei.udl.cat; $;{ }^{4}$ ana inesfernandez@ub.edu \\ *Corresponding author
}

\begin{abstract}
Phase Change Materials (PCM) can be employed in many fields because of their capacity to absorb and release energy when it is necessary. Nowadays, the number of studies about these materials is increasing because of their benefits in energy systems. This paper reviews the previous researches and developments on microencapsulated phase change materials (MPCM) in thermal energy storage (TES) systems, focusing on the different methods of encapsulations and also the different applications of these materials. This review aims to be a useful guide for the researchers in this area, because it explains the different types of phase change core materials, the different shells, the methods to microencapsulate these PCM, the most used techniques to characterize these microencapsulated phase change materials, and a revision of the main applications.
\end{abstract}

Keywords: Phase Change Material; Microencapsulated Phase Change Material; Thermal Energy Storage

\section{Introduction}

Phase Change Materials (PCM) are well known in Thermal Energy Storage (TES) applications [1-3]. PCMs are used to store energy when it is available, absorbing it and releasing it when needed. The most important requirements to be a good PCM may be divided in physical, chemical or economical requirements: 
- Physical requirements: Suitable phase change temperature, complete reversible freeze/melt cycle, large change in enthalpy $(\Delta \mathrm{H})$, large specific heat capacity $\left(\mathrm{C}_{\mathrm{p}}\right)$, large thermal conductivity (k), and little subcooling.

- Chemical requirements: Small volume pressure, low vapor pressure, good compatibility with other materials, chemical stability, physical stability, and non-toxicity.

- Economical requirements: Low price, recyclable and abundant.

PCM are used in several applications, due to the research done last forty years in this field. It had been published a total of 10,892 documents in TES field for the last 10 years (January 2005 - April 2015) [4]. Taking into account TES subject, if it is emphasized in PCM field, 2,319 documents can be counted. Following the same bibliographic search, but deepening and specializing the topic, the representation for the search in microencapsulated phase change material (MPCM) in TES field, is shown in Figure 1, with 449 documents for the last ten years (January 2005 - April 2015).

Figure 1.

These 449 documents related to MPCM were published in different subjects inside TES area. The most part were from Engineering (46.1\%), Materials Science (30.1\%), and Energy (28.1\%) journals, as Figure 2a illustrates. The studies connected with this thematic were produced in different kind of publications, such as articles (70.2 \%), conference papers (24.3 $\%$ ), and reviews (2.9\%), as examples showed in Figure $2 \mathrm{~b}$. Up to date, there are no reviews on MPCM.

Figure 2.

From these figures the study of PCM and MPCM is a topic that generates more interest every year. These materials can be applied in textiles [5,6], buildings [7-9], packaging, food, medical therapies, etc. PCM have been considered for TES in buildings since 1980, and only the PCM with a phase transition close to the human comfort can be used, which is around $20^{\circ} \mathrm{C}$. One of these applications for PCM is climatization [10], which has different uses, for example in solar cooling, as the study of Gil et al. [11] shows. Besides, inside the refrigeration area, food conservation [12,13] can be included. Oró et al. [14] studied the effect of the PCM introduction outer a freezer, improving the quality in the ice cream. The container drinks can also incorporate 
these type of materials to store energy, and release it when the systems needed, for example, the chilly bins studied by Oró et al. [15] to enhance the thermal performance. Also, it is possible to use phase change materials in cold storage needs, as Oró et al. [16] evaluate, studying the compatibility of PCM with metallic materials, but a common problem in PCM cooling applications is the subcooling, which happens when a material is cooled and the crystallization does not start below the freezing temperature [17].

Another very significant application of PCM is the one in the building sector [18], in passive applications like floors [19], walls [20-23] (for example conventional and alveolar brick [24]), and ceiling studies. There is another case, which is in active systems in domestic applications as heating [25] and hot water [26-29].

Since PCM undergo the solid-liquid states, they need to be encapsulated for their inclusion in the final system. Due to the leakage in the liquid state when mixing the PCM with other materials, such as building construction materials [30], and because of the corrosion and the thermal reliability, the possibility to make a polymeric container for PCM, in small vessels, using the encapsulation technology and producing capsules calling them encapsulated Phase Change Material for energy storage [31] has been investigated. Encapsulation techniques vary from macroencapsulation in slabs, panels, etc. to microencapsulation [32,33]. When the sizes of these capsules are micrometers, these are called Microencapsulated Phase Change Material (MPCM), which consisted on a polymeric shell and a core made of the storage material. The microencapsulation is a process of enclosing micron-sized particles of solids or droplets of liquids or gases in an inert shell, which in turn isolates and protects them from the external environment. The captivity of waxes into the microcapsules allows to increase the heat transfer [3] and to control de volume changes when the phase change is happening. Microencapsulation methodology for PCM still needs to be improved because the microcapsules can break easily when they collide with other microcapsules when they are used in active systems. Moreover, the shell has to be strong enough to sustain the stresses that are generated due to the volumetric changes during the phase change process of the PCM.

There are three requirements for the microencapsulation process: the formation of the shell around the desired PCM, guaranteeing that there is not leakage and ensuring that no impurities are included in the system core/shell MPCM. Besides, the thickness of the coating material has to assess the effectiveness of the encapsulated PCM. For this reason, the MPCM have to be highly resistant to mechanical and thermal stresses.

Two studies by Jamekhorshid et al. [34] and Sukhorukov et al. [35] explain that the size of the MPCM is very significant, because MPCM are more stable in the nanosize than in the 
microsize. They observed less mechanical deformation in $10 \mathrm{~nm}$ MPCM in size than in $10 \mu \mathrm{m}$. To avoid the breakage of the microcapsules, it is important to take into account the whole system we are using (shell/core). Moreover, the compatibility of plastics with PCM is a key point as Castellón et al. [36] evaluated, concluding that LDPE and PP show worst behavior compared with HDPE to encapsulate PCM. Hardness and Young's Modulus of different polymers were evaluated by Giro-Paloma et al. [37], because in passive systems case [38], the main problem of the leakage is the compression of this microcapsules inside the wall in a building [39].

As Kuznik et al. [23] studied, there are three relevant characteristics to evaluate for the quality of the MPCM: the mean diameter, the thickness of the shell, and the mass percentage of PCM compared to the total mass of the capsule. Once the PCM which will be used in a system as a good material to store energy is chosen, it is very important modeling the system with the finality to know how it will perform [40].

Microencapsulation has been studied widely by many researchers, but the literature is scattered. Therefore, this paper presents a review, which includes the different types of PCM that can be microencapsulated, the different shell materials used, the way to microencapsulate these PCM, and finally the most used techniques to characterize these MPCM with the idea to organize such literature and help researchers to use it as a guide in their future work. At the end of the review, the most important applications where MPCM are used are summarized. The future directions of research and development on Microencapsulated Phase Change Materials will focus on the improvement of characterization methodology for such complex materials, and deeply studying other relevant properties as the volatile organic compounds spread by MPCM, as well as their fire behavior.

\section{Types of Phase Change Materials (PCM)}

In microencapsulation, the core material is defined as the specific material to be coated and can be in liquid or solid state depending on the temperature. The composition of the solid core can be a single solid substance or a mixture of active constituents, stabilizers, diluents, excipients and release-rate retardants or accelerators [41,42]. There are three type of PCM: organic, inorganic and eutectic PCM. The most important property to take into account in a material to be used as a PCM is that it must have high thermal energy storage capacity, and in general, inorganic have it higher than organics, but there are some other subjects to take into account for 
choosing these materials. Cabeza et al. [43] listed in their review many PCM specifying their type, melting temperature, heat of fusion, thermal conductivity, density, and their source.

- Organic PCM: This type of PCM is further described as paraffinic and non-paraffinic. The principal advantages are their chemical and thermal stability, they are non-corrosive, recyclable and they have no subcooling. On the other hand, the disadvantages of using organic PCM are their flammability, their low thermal conductivity and a phase change enthalpy lower than other type of PCM. The most used ones are paraffin and fatty acids:

- Paraffin: This chemical is produced as a by-product of petroleum refinery. It consists of carbon and hydrogen atoms joined with single bonds with the general formula: $\mathrm{C}_{\mathrm{n}} \mathrm{H}_{2 \mathrm{n}+2}$, where $\mathrm{n}$ is the number of carbons (C). When $n$ is between 1 and $4 \mathrm{C}$ atoms the material is gaseous; between 5 and $17 \mathrm{C}$ is liquid, and for more than $17 \mathrm{C}$ is solid. It is considered a paraffin wax when the $\mathrm{C}$ is in the range of $20-40$.

- Fatty acids: It is a carboxylic acid with a long hydrocarbon chain of carbon (from 10 to 30) and hydrogen atoms with a general formula $\mathrm{CH}_{3}\left(\mathrm{CH}_{2}\right)_{2 \mathrm{n}} \mathrm{COOH}$. It has the carboxyl group $(\mathrm{COOH})$ at the end of the chain and due to the protection of this group, fatty acids based PCMs are non-toxic, with low corrosion activity, and chemically and thermally stable. Moreover, they can be found in natural products, not being a fossil fuel derivative. The fatty acids can be saturated or unsaturated, with one or more double bounds. Unsaturated fatty acids have lower melting points due to the molecular structure that allows closer molecular interactions. Moreover, unsaturated fatty acids can exist in the cis and trans configuration having the intermolecular interactions weaker than in saturated ones. Besides, different fatty acids can be mixed to design PCMs with different melting temperatures. There is a study of Suppes et al. [44] where the possibility to use natural fatty acid mixtures as high performance PCM is demonstrated.

- Inorganic PCM: They are classified as salt hydrates, salts, and metals. This type of materials has fewer advantages than organics. The pro is that they have higher phase change enthalpy, but the corrosion, subcooling, phase segregation, lack of thermal stability, and phase separation are the most important cons.

- Salt hydrates: It is defined as the inorganic salts that have water molecules combined in a definite ratio as part of the crystal, as $\mathrm{X}_{\mathrm{n}} \mathrm{Y}_{\mathrm{m}} \cdot \mathrm{aH}_{2} \mathrm{O}$ formula, where $X$ is a cation, $Y$ is an anion, and $a$ is the number of water molecules. They are solid at room temperature, 
and when the melting point is reached, the salt starts to dissolve in their own water crystal.

- Salts: They are inorganic salts with a formula as $\mathrm{X}_{\mathrm{n}} \mathrm{Y}_{\mathrm{m}}$, where $X$ is a cation and $Y$ is an anion. These salts are used for higher temperature ranges but they have lower enthalpy than salt hydrates. An example of a high temperature energy storage use is in a concentrated solar power (CSP) plant, which uses salt to store energy for later use.

- Metals: This subcategory of inorganic PCM includes the low melting metals and metal eutectics. They are good candidates to take into account for elevate temperature of phase change, when the volume is a consideration in the system, because of their high heat of fusion per unit volume. This type of PCM has high thermal conductivity, low specific heat, and low vapor pressure.

- Eutectics: The eutectics are a combination of chemical compounds or elements that has a single chemical composition and solidifies at a lower temperature than any other composition obtained from the same components. The combinations can be organicorganic, inorganic-inorganic, or inorganic-organic [45]. There are numerous eutectic mixtures suitable to be used as PCM, and they are preferred in cooling applications.

\section{Types of shell}

There are over fifty different polymers known that can be used as wall materials in microencapsulation; both natural and synthetic polymers controlling release under specific conditions. The shell coating materials have to have some properties or requirements. The polymer should be capable of forming a thin film that it must be cohesive with the core material, being tasteless, pliable, and stable. It should be chemically compatible and nonreactive with the core material, and also soluble in an aqueous media or solvent. Moreover, it should provide the desired coating properties such as strength, flexible, impermeable, optical properties, and stability. The film thickness can be varied considerably depending on the surface area of the material to be coated, and other physical characteristics of the system. Besides, the shell coating material has to be non-hygroscopic, with medium/low viscosity, and low cost.

\section{Types of Microencapsulated Phase Change Materials (MPCM)}


There are several studies about MPCM, where choosing the combination shell/core is the most important point. The proportion of core material in the capsule is usually between 20 and $95 \%$ by mass [46]. The microcapsules may consist on a single particle or clusters of particles.

Paraffin wax is one of the most employed PCM in MPCM systems. Among paraffin, $n$ octadecane is the PCM most used microencapsulated in building applications [47-51].

There are a lot of studies about the shell. One possibility is the transparent and thermoplastic acrylic polymer for the shell [42,52-55], such as poly(methyl methacrylate) (PMMA) [56-60]. It has good mechanical properties and good protection against the environment. For these reasons, PMMA is an adaptable material and it is a good polymer as shell material in the preparation of MPCM for thermal energy storage applications. Moreover, as example of commercial MPCM, BASF ${ }^{\circledR}$ has a variety of products with PMMA as shell material. As examples of studies with $\mathrm{BASF}^{\circledR}$ materials, Tzevetkov et al. [61] studied one of the products, Micronal ${ }^{\circledR}$, using scanning transmission X-ray spectromicroscopy. This PMMA has good compatibility with a wide variety of PCM, for example with fatty acids, such as stearic acid, palmitic acid, myristic acid and, lauric acid as studied by Alkan et al. [62]. Besides, GiroPaloma et al. [63] evaluated in detail the physical, chemical and mechanical properties of Micronal ${ }^{\circledR}$ DS 5001.

Another polymeric shell very employed is the melamine-formaldehyde (MF). Su et al. [64] studied the influence of the temperature in the deformation, concluding that the yield point of MPCM decreased with the increasing of temperature. Also, Palanikkumaran et al. [65] used the MF shell to contain $n$-octadecane as PCM using the in-situ polymerization technique.

In Table 1 a list of some manufacturers' trademark name, the PCM they use, the shell material, and the particle size distribution (PSD), and its application is shown.

Table 1.

\section{Methods to encapsulate PCM}

The system core/shell is a key point in the fabrication of microcapsules, being the shell function to protect the core, and the core function to contain the active material, in this case the PCM. The MPCM's morphology can be diverse as Figure 3 shows, but the most common are the spherical and the irregular ones. 
Figure 3.

The microcapsule description and their morphology depend on the core material and the deposition process of the shell. There are four types, as Figure 4 shows:

a) Mononuclear (core/shell): a single core wrapped with a continuous shell material

b) Polynuclear: many cores coated with a continuous shell material

c) Matrix encapsulation: in which the core material is distributed homogeneously into the shell material

d) Multi-film: a continuous core coated with multilayer continuous shell material

Figure 4. [66]

There are three different methodologies to microencapsulate PCM based on the mechanisms of microparticle formation: chemical, physical and chemical, or physical and mechanical mode.

- Chemical methodology: Suspension, dispersion, emulsion, in situ and interfacial polymerization, or polycondensation are different procedures widely employed for the fabrication of PCM microcapsules (MPCM). Table 2 enumerates the advantages and the drawbacks of each procedure.

- Suspension polymerization: Sánchez-Silva et al. [67] exposed that the suspension polymerization process is governed by multiple simultaneous mechanisms such as particle coalescence and break-up, secondary nucleation, and the diffusion of monomer to the interface. The collective effect of these mechanisms confers the size, the structure and the surface properties to the microcapsules. Figure 5 shows a scheme of the suspension polymerization methodology. Sánchez et al. [68] developed a method based on a suspension free radical polymerization process to fabricate microencapsulated non-polar PCM. The same authors [69] investigated the influence of the reaction temperature, the stirring rate and the mass ratio of paraffin to styrene on the thermal properties of MPCM. Borreguero et al. [70] considered the microencapsulation by suspension polymerization with gypsum in two steps: a continuous one formed by deionizated water and the stabilizer (Polyvinyl-pyrrolidone, PVP), and a discontinuous one containing the styrene monomer, the paraffin wax and the benzoyl peroxide. As main result they achieve an improvement of the thermal insulation capacity of the gypsum by the addition of the prepared MPCM. 
Figure 5 .

- Dispersion polymerization: Dispersion polymerization is a very attractive method due to its inherent simplicity of the single-step process. Typical examples of this method are the dispersion polymerization of styrene in hydrocarbons, alcohols, alcohol-ether and alcohol-water mixtures. In this methodology it is important to control the parameters such as initiator, monomer, stabilizer concentration, and the reaction time on the characteristics of the final particles with this methodology. One way to do it is by UV photo-initiated dispersion polymerization of stearic acid in PMMA shell as described by Wang et al. [71], which has high efficiency as they exposed in their study. Kim et al. [72] show that monodisperse poly(methyl methacrylate) microspheres were successfully synthesized by the dispersion polymerization using hydrophilic polyvinylalcohol (PVA) in a methanol/water mixture media. Figure 6 presents a graphic description of the dispersion before and after the polymerization process.

Figure 6. [73]

- Emulsion polymerization: This method consists on mixing the polymer in an oiled system, adding an emulsifier. After this, an emulsification is needed, to create a water/oil emulsion and to generate a crosslinked system (chemically, thermally, or in an enzymatic way). The final step is washing the emulsion, to remove the oil and to create the isolated microcapsules. In Figure 7 a scheme of this methodology can be observed. Sar1 et al. [74] used this technique to prepare and characterize the MPCM for TES of PMMA as shell and $n$ heptadecane as PCM.

Figure 7. [75]

- In situ polymerization: In this methodology the capsule shell formation occurs because of the polymerization of monomers added to the reactor. In this process no reactive agents are added to the core material and polymerization occurs exclusively in the continuous phase. This method to microencapsulate PCM has to have all the materials for the microcapsule wall 
originate from continuous phase of the emulsion system, and have to be water soluble [76]. Initially a low molecular weight pre-polymer will be formed, as time goes on the pre-polymer grows in size, it deposits on the surface of the dispersed core material thereby generating solid capsule shell [77]. First, a PCM emulsion is prepared and then the synthesis of the pre-polymer solution is carried out through the mixture of two polymers, which will form the cover, and water. This pre-polymer is added to the emulsion in the form of droplets, while the emulsion is agitated during a specific time. The emulsion is cooled and filtered, obtaining the microcapsules, which have to be dried. To enhance the mechanical properties, it is suggested to add modifying agents [78]. Boh et al. [79] have used a modified in situ polymerization method with melamine-formaldehyde pre-polymers as wall materials and styrene-maleic acid anhydride copolymers as modifying/emulsifying agents. Furthermore, Boh et al. [80] define this technique as the procedure where monomers or pre-condensates are added only to the aqueous phase of emulsion. Moreover, Yang et al. [81] studied the best shell to encapsulate tetradecane as PCM with polystyrene (PS), PMMA, poly(ethyl methacrylate) (PEMA) and polyvinyl acetate (PVAc) as Phase Change Slurries (PCS) using this technique, and the study concludes that PMMA and PEMA are the best shells. After this study, Yang et al. [82] had used the same PCM contained in different shell materials, Acrylonitrile-styrene copolymer (AS), acrylonitrile-styrenebutadiene copolymer (ABS), polycarbonate (PC), concluding that all the three shell materials could be used to microencapsulate $n$-tetradecane. Using this same PCM, Fang et al. [83] encapsulated it with urea and formaldehyde, concluding that the $n$-tetradecane encapsulation is efficient with good thermal stability and attractive for thermal energy storage and heat transfer applications. Besides, Chen et al. [84] synthesize and characterize MPCMs made of paraffin/ $/ \mathrm{SiO}_{2}$ obtained by this process, being a good MPCM because the $\mathrm{SiO}_{2}$ protect the paraffin from reacting with the outside environment. Finally, there is a study of Song et al. [85] where MPCM with hexadecane as core material were prepared by this methodology by using urea-formaldehyde resin and urea-formaldehyde resin modified with melamine as shell materials respectively, concluding that the addition of melamine into the urea-formaldehyde resin reduced the microcapsule size and the microencapsulation efficiency. Moreover, the effects of the system concentration, the agitation speed and mass ratio of the wall are key factors to take into account, as it is referred in the last references.

- Interfacial polymerization: In this technique the shell capsule is formed at or on the surface of the droplet or on the particle by polymerization of the reactive monomers, and involves dispersing an organic phase (containing poly-functional monomers and/or oligomers) into an aqueous phase (containing a mixture of emulsifiers and protective colloid stabilizers) along with the material to be encapsulated. The presence of crosslinks affects the morphology of the external microcapsule surface [86]. The substances used as a shell are multifunctional 
monomers. The multifunctional monomer is dissolved in liquid core material and it will be dispersed in aqueous phase containing a dispersing agent. Generally, used shell forming material includes co-reactant multifunctional reagent like diamines, isocyanates and diacid chlorides. These results in rapid polymerization at the interface and the generation of the capsule shell takes place [77]. The main advantages of this technique are the high reaction speed, mild reaction course, and also that its products have low penetrability. Liang et al. [87] [46] succeed with the interfacial polymerization to prepare MPCM of butyl stearate as a PCM in a polyurea system. Li et al. [88] fabricated nanoparticles of $\mathrm{SiO}_{2} /$ paraffin using this process of polymerization and concluded that the methodology can be extended to fabricate other organic and inorganic PCM with different core/shell compositions. Figure 8 shows a scheme of interfacial polymerization where it is highlighted that high pressure is needed to obtain MPCM.

Figure 8. [89]

Table 2 shows the advantages and disadvantages of the different techniques for chemical methodology described.

Table 2.

- Physico-chemical methodology: It includes coacervation, layer-by-layer assembly, sol-gel encapsulation and supercritical $\mathrm{CO}_{2}$-assisted methods. Table 3 lists the advantages and disadvantages of each technique in the physico-chemical methodology.

- Coacervation: There are described two methods for coacervation process, the simple one and the complex one. The microcapsule formation mechanism for both processes is the same, with the exception on the way in which the phase separation is carried out. For simple coacervation, a desolvation agent is added for phase separation. By contrast, a complex coacervation involves complexation between two oppositely charged polymers. Figure 9 shows a scheme of this procedure.

Figure 9. [90] 
Besides, there are three steps in complex coacervation. The first step is the formation of three immiscible phases, the liquid manufacturing vehicle, the core material, and the coating material. The core material is dispersed in a solution of the coating polymer. It is needed a changing temperature of polymer solution and a addition of salt, nonsolvent, and of an incompatible polymer to the polymer solution. The second step is the deposition of the coating, and the third step is the coating rigidization. The prepared microcapsules are stabilized by crosslinking, desolvation or thermal treatment. Figure 10 shows the steps involved in the complex coacervation technique.

Figure 10.

In the complex process, the polymeric solute is separated in the form of small liquid droplets, forming the coacervate. Then, it is deposited around the insoluble particles dispersed into a liquid. These droplets slowly unite and form a continuous cover around the core. In order to obtain a longer lifetime of microcapsules, this technique can be completed in two steps, adding the polymer twice. Through this mechanism, a smaller thickness of the microencapsulate shell can be obtained. Compactability and impermeability are improved (a lower speed of polymer deposition increases impermeability), giving greater stability to the microcapsules, conserving size and spherical form. The texture is smoother and the spherical form is more regular, compared to one-step coacervation, where microcapsules with many protrusions, rougher, coarser and more porous are obtained. Hence, it is a phenomenon which takes place in colloid systems, where macromolecular colloid rich coacervate droplets surround dispersed microcapsule cores, and form a viscous microcapsule wall, which is solidified with crosslinking agents. Özonur et al. [91] used this technique concluding that gelatin + Arabic gum mixture was the best wall material for microencapsulating coco fatty acid mixtures compared with urea-formaldehyde resin, melamine-formaldehyde resin, and $\beta$-naphtol-formaldehyde.

- Sol-gel encapsulation: This methodology is described as the formation of an oxide association through polycondensation reactions of a molecular predecessor in a liquid. A sol is a stable dispersion of polymers or colloidal particles in a solvent, where the particles can be crystalline or amorphous. On the other hand, a gel consists on a three dimensional continuous network, which includes a liquid phase, building an agglomeration of colloidal particles. Besides, in a polymer gel the particles have a polymeric substructure composed by aggregates of subcolloidal particles. In general, the sol particles interact by Van der Waals forces or hydrogen bonds, but can also be formed from linking polymer chains. Fang et al. [92] used the 
sol-gel methodology to prepare form stable lauric acid/silicon dioxide composite PCM. This material can be used for TES in waste heat recovery as well as solar heating systems. Li et al. [93], using the sol-gel methodology, prepared a shape-stabilized paraffin/silicon dioxide composite PCM. Also, Tang et al. [94] enhanced the thermal conductivity of $\mathrm{PEG} / \mathrm{SiO}_{2}$ via in situ chemical reduction of $\mathrm{CuSO}_{4}$ through ultrasound-assisted sol-gel process, concluding that the $\mathrm{Cu} / \mathrm{PEG} / \mathrm{SiO}_{2}$ hybrid material have excellent thermal stability and a good-stable performance. Figure 11 shows a scheme of the sol-gel process.

Figure 11. [95]

- Supercritical $\mathrm{CO}_{2}$-assisted: Supercritical carbon dioxide has attracted a great deal of attention as an alternative to the conventional processing because it is an effective and green synthetic method. Supercritical $\mathrm{CO}_{2}$-assisted have gained a strong interest in the synthesis of polymeric composites because it has low critical temperature value, is non-toxic and has nonflammable properties. Moreover, it is readily available, highly pure and cost-effective. Wu et al. [96] used this technique studying the effects of some factors on the particle size of PMMA particles prepared via a supercritical assisted-atomization (SAA) process using acetone as a solvent and supercritical carbon dioxide as a spraying medium. These factors included the concentration of polymer solution, temperature in saturator and volumetric flow rate ratio of carbon dioxide to polymer solution. More recently, Haldorai et al. [97] has summarized on the synthesis of polymer-inorganic filler nanocomposites in supercritical $\mathrm{CO}_{2}$ and conclude that although there are three methods for the preparation of nanocomposites (blending, sol-gel and in situ polymerization), the super-critical $\mathrm{CO}_{2}$ has been demonstrated to be a viable alternative to the conventional solvents.

Table 3.

- Physico-mechanical methodologies include spray-drying, electrostatic encapsulation, and one-step method. These techniques are inherently not capable of producing microcapsules smaller than $100 \mu \mathrm{m}$ [66]. In Table 4 the benefits and disadvantages of each technique in the physical and mechanical methodology is listed. 
- Spray-drying: it is a low-cost commercial process which consists on the preparation of an emulsion, dispersing the material of the PCM in a concentrated solution of the material forming the capsule, until the desired size of the microcapsule is achieved. Then, this emulsion is pulverized into droplets. Afterwards, it will be dried, evaporating the water, which let the active material to be trapped inside a film of encapsulating material. This technique involves the atomization of a homogeneous liquid stream in a drying chamber where the solvent is evaporated and solid particles are obtained. It is suitable for heat-sensitive materials. This technique was studied by Borreguero et al. [98] mixing LDPE and EVA to create the polymeric shell. They chose these two polymers due to their similarity of the chemical structure, besides the low density, their versatility, and the inexpensive cost. Moreover, Hawlader et al. [99] and Fei et al. [100] used also this technique to produce other types of microcapsules, using different shells (formaldehyde and titania, respectively), and cores (Gum Arabic, paraffin wax, and noctadecane, respectively).

- Electrostatic encapsulation: This technique is effective for production of particles, around $100 \mu \mathrm{m}$. It might be used to prepare spherical microbeads with a hydrophobic core and a hydrophilic or hydrophobic shell [101].

- One-step method: The benefits of using this method include easy scale-up and no need for a stabilizing agent due to self-stabilization. It allows tuning of the size and polydispersity of the capsules, and the use of different core materials. Jin et al. [102] uses this methodology without surfactants or dispersants nor acids/bases for stabilizing the capsules via oil/water emulsion, and the obtained results shows that the method allows tuning of the size and polydispersity of the capsules, and the use of different core materials.

Table 4.

\section{Phase Change Slurries}

Phase Change Slurries (PCS) [103] is another important part of MPCM [104,105]. When the MPCM is fabricated in a dried state $[106,107]$ it can be mixed with a carrier fluid, mainly water [108] or with other substances such as glycol [109,110] or glycerol [111,112], creating a PCS. These are widely employed in several fields, such as pumping active systems [113,114], using them for refrigeration [103,115], in air conditioning [116,117], in heat exchangers [118], heating [119], ventilation and air-conditioning (HVAC) [120-122], in solar energy [123], in 
cold storage [124], and heat exchangers [118] applications. As Salunkhe et al. review [125], the PCS not only acts as an energy storage device but also as a heat transport system. The way of pumping the slurries in an active system is very important $[113,126]$, because it is know that microcapsules can broke when they collide ones to each other. Moreover, Zeng et al. [127] studied numerically the influences of microparticles and phase change in fluid-pure water, PCS and MPCM. Besides, Huang et al. [128] and Günter et al. [129] studied the subcooling in PCM emulsion, remarking that in PCS applications, the changed nucleation and solidification behavior is critical.

\section{Characterization of MPCM}

\subsection{Experimental characterization techniques reported in the study of MPCM}

\subsubsection{Particle Size Distribution (PSD)}

For the evaluation of the microspheres' size and the percentage in number or in volume of each size, is used laser diffraction spectrometry. The results must be evaluated taking into account the size as well as the transparency of the MPCM, so there are two mathematical models to do so: Mie and Fraunhofer [130]. Mie model fits better for homogenous and spherical particles, opaque or transparent and with diameters below $30 \mu \mathrm{m}$. Also, to calculate the size of the microcapsule it is needed the refractive index and the absorption of the substance. For using the Fraunhofer model is needed opaque particles bigger than $30 \mu \mathrm{m}$. Most of the MPCM evaluation studies included this technique. Yu et al. [131] used this technique to study the diameter distribution of MPCM prepared with different mass ratios of emulsifier to PCM.

\subsubsection{Optical Microscopy (OM)}

This technique provides images of microspheres with a good resolution, allowing the evaluation of their morphology, fixation, durability, and without a complex sample preparation. Sánchez et al. [5] used in their study transmitted light and reflection mode to develop thermo-regulating textiles using MPCM of paraffin in the core. Besides, Bayés-García et al. [132] characterize MPCM with Gelatine/Arabic Gum (G/AG) by using a thermo-optical microscope at different temperatures.

\subsubsection{Scanning Electron Microscopy (SEM)}


This technique is essential to evaluate the shape and size of the MPCM. Besides it is useful to study the surface of the microcapsules, as well as if there is PCM spread. It is a fast technique and it is widely employed. Bajare et al. [133] studied the shell thickness of $\mathrm{BASF}^{\circledR}$ Micronal $^{\circledR}$ DS 5001x by using this technique.

\subsubsection{Transmission Electron Microscopy (TEM)}

The morphology and the structure of the microcapsules can be observed also by TEM, when their size is below micrometers, as Pan et al. [134] evaluated for nanostructures prepared through in-situ interfacial polycondensation, resulting colloidal sphere microcapsules with diameter around $200 \mathrm{~nm}$.

\subsubsection{X-Ray Diffraction (XRD)}

This technique is used to analyze the crystalloid phase of the microencapsulated paraffin, like Fang et al. [135] show in their study, synthesizing and characterizing MPCM paraffin composites with $\mathrm{SiO}_{2}$ shell. Moreover, this technique is used to assure the encapsulation of the PCM, as Fang et al. [136] used XRD patterns of $n$-octadecane, styrene and the nanoencapsulated PCM, suggesting that $n$-octadecane was successfully encapsulated by the shell of polystyrene. So, this technique plays an important role on studying the prevention of leakage of PCM.

\subsubsection{Wide Angle X-ray Scattering (WAXS) and Low Angle Laser Light Scattering (LLALS)}

The crystalline structure of polymers and PCM can be examined by this technique. It is convenient to evaluate the crystallographic forms of the encapsulated PCM. Zhang et al. [137] analyzed the WAXS patterns of the MPCM with different weight ratios of core/shell ( $n$ octadecane/resorcinol-modified melamine-formaldehyde) materials. Moreover, Sánchez-Silva et al. [67] had used LLALS technique to better characterize the MPCM styrene-methyl methacrylate copolymer shell.

\subsubsection{Fourier Transformed Infrared Spectroscopy (FT-IR)}

This technique is used to evaluate the microcapsule shell material, as well as to study the possible degradation of the external part of the microsphere. It can be analyzed by Attenuated 
Total Reflectance (ATR) or with a $\mathrm{KBr}$ pellets [138]. An example of this use is the study of Zhang et al. [139] whom characterize the polycarbonate shell before and after 1000 thermal cycles to evaluate the matrix thermal distortion temperature.

\subsubsection{Differential Scanning Calorimeter (DSC)}

This is one of the most popular thermal analysis techniques. It measures endothermic and exothermic transitions in function of the temperature. It also can detect glass transitions, fusion, crystallization, and oxidation. It can measure specific heat capacities [140]. For these reasons, this technique is widely employed to characterize the thermophysical properties of MPCM. It provides the melting and solidifying temperature, as well as, the melting and solidifying enthalpy of a sample, revealing if the material has a good capacity to store energy. Ostrý et al. [141] confirmed by DSC technique the suitability of some PCM for their integration in building structures. Table 5 summarizes the main thermal properties (latent heat and phase change peak temperature) of the MPCM analyzed in this review, describing the composition of the core and shell material.

Table 5.

\subsubsection{Thermogravimetrical Analysis (TGA)}

This technique measures the amount and rate of change in the weight of a material as a function of temperature or time in a controlled atmosphere. Measurements are used primarily to determine the composition of materials and to predict their thermal stability. The technique characterize materials that exhibit weight loss or gain due to decomposition, oxidation or dehydration and also their thermal stability. There are a lot of studies using it. Zhang et al. [142] evaluate the step thermal degradation of a silica/n-octadecane MPCM, as well as the thermal reliability by using this technique.

\subsubsection{Atomic Force Microscopy (AFM)}

It is a surface technique which has the ability to obtain topographic images of surfaces with nanometric resolution. It can be used as a nanomanipulator in order to move and test the surface of the samples in a variety of ways, such as electrically, magnetically and mechanically. The microcapsules' mechanical properties can be evaluated by using this technique. The microcapsule maximum force and the total deformation of an individual microcapsule [98] have 
to be measured increasing the applied force until obtaining the typical force displacement curves. It is necessary to repeat this procedure several times (at least 3 times). Furthermore, it can be extracted the deformation histogram and the Young's modulus histogram taking into account a small area on the top of the microcapsule. Giro-Paloma et al. [143] evaluated the maximum force that a dried PCS can support on the top of the microsphere using Atomic Force Microscopy (AFM) technique. Besides, Giro-Paloma et al. [63] also evaluated the maximum force that the MPCM Micronal ${ }^{\circledR}$ DS 5001 can support before their breakage at three different temperatures: $25^{\circ} \mathrm{C}, 45^{\circ} \mathrm{C}$ and $80^{\circ} \mathrm{C}$ by using this technique. They conclude that the required applied load in order to break the sample depends on the working temperature. Hence, the temperature is a key point to take into account when a PCM have to be chosen for a specific application.

\subsubsection{Emission of Volatile Organic Compounds}

The volatile organic compounds (VOC's) evaluation at different temperatures is an important issue to better characterizing PCM and MPCM. Materials for indoor environments should not emit hazardous gases in the form of volatile organic compounds. There are studies over the past decade of measuring the air quality (indoor environment) in building materials through volatile organic compounds (VOC's) because they play a major role in construction [144-155]. Therefore, the VOC's emission from building materials can be studied experimentally and theoretically (using mathematical models) to predict the quality of indoor air. There are some others studies about the outdoor environment [156,157]. Also, it is studied that multi-layer materials have much longer VOC's emission time and a slower VOC's decay rate compared with single-layer materials [158]. Moreover, it has to take into account that the adsorption/desorption phenomena of relatively high vapor pressure compounds are negligible in building [159]. Besides, the percentage of approximately $40 \%$ of the indoor air quality levels originated from building materials [160] are VOC's associated with the perception of bad odors. In buildings which are renovated or new (considering new buildings that are less than 10 years old) the levels of indoor air pollutants are higher than the VOC's levels in aged buildings [161].

Implementing MPCM in gypsum board, concrete, plaster or other wallboard material, thermal storage can be a part of construction technology for light weight buildings, and the MPCM could be used for high density thermal energy storage [162,163], so the final product would achieve energy savings in buildings. The fact of using gypsum, cement and heavyweight sheet with PCM could produce some VOC's in the indoor air in a cubicle $[164,165]$. Consequently, it is important to preserve the air quality of a room. Hence, it is used MPCM to reduce the toxic effects that could be expelled in a system [166]. Although using MPCM mixed 
with other constructive materials, there is a main concern on the use of organic PCM because of the possible emission of volatile compounds [157,167]. Due to most commercial PCM microcapsules have not been well characterized for volatile emission, a proposition for future studies could be to characterize and measure the volatile organic compounds for PCM, MPCM and constructive materials containing these kind of materials."

\subsection{Properties to analyze}

\subsubsection{Flammability}

Due to the lower thermal stability and inflammability properties of MPCM, their usage has been severely restricted especially in building applications [50]. For this reason, the studies of determining the flammability properties of MPCM are of importance in many applications. The Cone calorimeter is one of the most effective bench scale methods for investigating the combustion properties of polymer materials. Cai et al. [168] evaluate this property on formstable PCM based on paraffin/ high density polyethylene (HDPE) composites with expanded graphite (EG) and ammonium polyphosphate (APP) flame retardant system.

\subsubsection{Viscosity measurement, density, and conductivity}

The viscosity of melted PCM or PCS is very important in flowage and is important to measure it at different temperatures with a rotation viscosimeter. High viscosity will increase the pump energy consumption.

Another important property to take into account in a PCS system is the density $\left(\rho_{P C S}\right)$ which is given by Equation 1, where $X_{i}$ is the weight fraction and $\rho_{i}$ is the density of each component:

$$
\rho_{P C S}=\mathbf{1} / \sum_{\mathrm{i}} \frac{\mathbf{x}_{\mathbf{i}}}{\rho_{\mathrm{i}}}
$$

Density can be obtained by using a specific gravitymetre or a pycnometer by determining the volume.

Another property used to characterize MPCM and PCS is the thermal conductivity $(k)$, which can be calculated in different ways, as Youssef et al. [94] report in their review. One way to calculate the thermal conductivity of a MPCM is by Maxwell's et al. [169] relation:

$$
K_{M P C M}=K_{\text {cont }} \frac{2+{ }^{K_{M P C M}} / K_{\text {cont }}+2 C_{M P C M}\left({ }^{K_{M P C M}} / K_{\text {cont }}-1\right)}{2+K_{M P C M} / K_{\text {cont }}-C_{M P C M}\left({ }^{K_{M P C M}} / K_{\text {cont }}-1\right.} \quad \text { Equation } 2
$$


Furthermore, Wang et al. [170] evaluated these three properties in a microencapsulated phase change material (MPCM) slurry flow in a circular horizontal tube. The viscosity was evaluated as well as the density of the slurry, which was calculated by weighted fraction of the densities of PCM, the coating material, and the water, based on the mass and energy balance. The thermal conductivity of the microcapsule was calculated based on a composite sphere approach.

\subsubsection{Cycling}

The thermal cycling test reveals the thermal reliability and chemical stability of a microcapsule [171]. For this reason, it is an essential test to evaluate the quality of the microcapsules to assure the no alteration on its geometrical profile after several cycles $[172,173]$. The thermal reliability can be evaluated in a DSC device, as Fortuniak et al. [174] used to withstand 50 fusioncrystallization cycles tests, or in a thermocyclator. There is another study by Sar1 et al. [56] where it was tested the thermal cycling test with 5000 cycles of a PMMA shell and $n$ octacosane PCM.

\section{MPCM applications}

In between the applications of MPCM, the use of MPCS for cooling in Narita Airport (Tokyo, Japan) can be found [115]. Here MPCS was used to compensate the decrease of energy capacity caused when the refrigerant was substituted due to environmental reasons. The slurry used is the mixture of water and $2 \mu \mathrm{m}$ microcapsules, and the melting temperature and the corresponding latent heat of which are $8{ }^{\circ} \mathrm{C}$ and $75.9 \mathrm{~kJ} \cdot \mathrm{kg}^{-1}$, respectively. The storage tank is $24.7 \mathrm{~m}$ in height and $7.4 \mathrm{~m}$ in diameter. Cold energy is stored during night time and released during day time.

Another interesting application of MPCM is in buildings. Here active and passive systems can be considered. In active systems, MPCS are involved, since the MPCM needs to be movable. Griffiths et al. [175] investigated the use of MPCS in a ceiling panel. MPCS with a melting temperature of $18{ }^{\circ} \mathrm{C}$ and $2-8 \mu \mathrm{m}$ microcapsules produced by BASF (40\% concentration) was used as heat transfer medium in a test chamber (with working temperature of $16-18{ }^{\circ} \mathrm{C}$ ).

As for passive systems, MPCM have been combined with different building materials, such as gypsum, concrete [140,176-181], and insulating materials, and tested in different set-ups. In 2005, Schossig et al. [182] presented the results of adding PCM in plaster and testing the new product in real offices. Since comparison was quite difficult due to the influence of users, two new full-size test rooms with a lightweight construction at the facade testing facility and coated 
the interior walls with PCM plaster and reference plaster were built. The measured data showed the potential for PCM products to reduce the cooling demand and increase the comfort in lightweight buildings. Later, MPCM incorporated in gypsum boards has been investigated by many researchers [70,183-185].

The performance of PCM in building structures are usually investigated via a dynamic building performance simulation. In order to avoid the need of measuring the thermal properties each time the composition changes, Toppi et al. derived experimental correlations to calculate the composite material properties as function of its composition [186]. Such correlations may also be used, when choosing the material composition, in order to obtain the required properties. The correlations are based on experimental results obtained from gypsum based composite material containing BASF MPCM.

Cabeza et al. [162] and Castellón et al. [187] developed a new innovative concrete with microencapsulated phase change materials (MPCM) without losing any of the initial concrete characteristics and achieving high energy savings in cooling. The experimental setup used consisted of two identically shaped cubicles of concrete, one with conventional concrete, and the other one with the modified concrete which included MPCM. The MPCM used was a commercial microencapsulated PCM called Micronal ${ }^{\circledR} \mathrm{PCM}$ (from BASF) with a melting point of $26{ }^{\circ} \mathrm{C}$, and a phase change enthalpy of $110 \mathrm{~kJ} \cdot \mathrm{kg}^{-1}$. The developed concrete reached a compressive strength over $25 \mathrm{MPa}$ and a tensile splitting strength over $6 \mathrm{MPa}$ (after 28 days). Moreover, concrete panels were produced in a way close to common concrete production methods. The results of this study showed improved thermal inertia as well as lower inner temperatures, demonstrating a real opportunity in energy savings for buildings.

One of the main drawbacks found in this experimentation was the severe influence of high outdoor temperature peaks and solar radiation over the PCM during the summer, which prevented its solidification during night and thus diminished its achievable potential benefits. Therefore, Arce et al. [9] tried to overcome such a problem and to increase the operation time of the PCM and the thermal comfort achieved. For such a purpose, in 2008 - 2009 similar experiments have been performed with awnings added to the set-up, providing them with solar protection. Results showed that peak temperatures were reduced about $6 \%$. Moreover, PCM remained active for at least $4 \%$ more hours, and the comfort time was increased at least $10 \%$ in cubicles with awnings.

MPCM was also added to sandwich panels [188] to increase their thermal inertia and to reduce the energy demand of the final buildings [186]. To manufacture the sandwich panel with microencapsulated PCM three different methods were tested. In case 1, the PCM was added 
mixing the microencapsulated PCM with one of the components of the polyurethane. In the other two cases, the PCM was added either a step before (case 2) or a step after (case 3) to the addition of the polyurethane to the metal sheets. The results show that in case 1 the effect of PCM was overlapped by a possible increase in thermal conductivity, but an increase of thermal inertia was found in case 3 . In case 2, different results were obtained due to the poor distribution of the PCM. Some samples showed the effect of the PCM (higher thermal inertia), and other samples results were similar to the conventional sandwich panel. In both cases ( 2 and 3 ), it is required to industrialize the process to improve the results. In these experiments, $8 \%$ in weight of MPCM with respect to the weight of the PUR was added. Here also Micronal ${ }^{\circledR}$ PCM (from BASF) with a melting point of $26^{\circ} \mathrm{C}$ was used.

Similarly, Borreguero et al. developed new rigid polyurethane foam containing microencapsulated Rubitherm RT27 [189]. $21 \mathrm{wt} \%$ content of MPCM could be incorporated in RPU foams, improving the TES capacity of these materials but depressing their mechanical properties. Results indicated that the foaming process was affected by the microcapsules content decreasing the foam rising rate and its final size. Later on, they used catalyst Tegoamin 33 in the process, being able to include $18 \mathrm{wt} \% \mathrm{MPCM}$ in the foam maintaining the mechanical properties of the neat foam, and catalyst Tegoamin BDE, being to include $21 \mathrm{wt} \%$ MPCM with higher mechanical resistance than the previous foams [190]. Finally, rigid polyurethane (RPU) foams were synthesized incorporating up to $18 \mathrm{wt} \%$ of two different kinds of thermo-regulating microcapsules having a different shell material consisting of polystyrene or poly(methyl methacrylate), named as mSP-(PS-RT27) and Micronal ${ }^{\circledR}$ DS 5001x, respectively [191]. The type of microcapsules and their content affected the final foam height, which decreased with the content and particle size. However, the foam rising curve shape was not dependent on the microcapsules type or content and was successfully predicted by means of a model of reaction curve of four tanks in series. Thermal energy storage (TES) capacity of PU foams was improved by incorporating both, mSP-(PS-RT27) or Micronal ${ }^{\circledR}$ DS 5001x, with the values close to those reported in the literature $\left(16 \mathrm{~J} \cdot \mathrm{g}^{-1}\right)$ for the highest content. Nevertheless, the highest particle size of the microcapsules from PS and the agglomeration of the microcapsules from poly(methyl methacrylate), promoted by their additive $\mathrm{SiO}_{2}$, led to the strut rupture, damaging the final mechanical properties.

One of the first applications where MPCM was used is in textiles to enhance thermal comfort in clothes [5,192-195] and, more recently, footwear [196]. In this last application, for example, a nonwoven fabric, three foams and leather, commonly used as fabrics for shoe manufacturing, were doped with microcapsules containing phase change materials (PCMs) and also with carbon nanofibers $(\mathrm{CNFs})$ in order to improve the thermal comfort provided by the shoes. The 
maximum microcapsule content that can be incorporated and the influence on the weight, thickness and the thermal properties and behavior of the fabrics were evaluated. The resulting materials showed a thermal energy storage (TES) capacity up to $13.74 \mathrm{~J} \cdot \mathrm{g}^{-1}$ and a maximum thickness increase of the composite fabric of $0.6 \mathrm{~mm}$. The PCMs addition promoted a slight modification of the steady-state temperatures of the fabrics subjected to heating or cooling processes and the stored and released heats confirmed that PCMs work in a reversible way. On the other hand, the addition of CNFs compensated for the insulating effect of the PCMs. Finally, it was found that footwear containing these materials could hold the foot temperature for a longer time than parent fabrics.

\section{Conclusions}

In this paper, classification of the research carried out in microencapsulation of PCM is presented with the aim of rationalize the scattered material on the topic available in the literature. The different types of PCM, the different shell materials used, the methods of encapsulation, the most used techniques for their characterization, and the main applications are the different sections presented.

PCM can be organic and inorganic; up to now, mainly organic PCM have been encapsulated, with a big focus in paraffin and fatty acids. Only recently, microencapsulation of salts and salt hydrates is presented by some researchers. Only a few manufacturers of MPCM have been identified. When MPCM are used as heat transfer fluid they are presented as phase change slurries (PCS).

Both natural and synthetic polymers can be used as shell material; this review shows that many different polymers have been used, depending on the requirements of the PCM and the application considered. The combination core/shell is one of the most important parameters in microencapsulation.

The morphology of the microcapsules in MPCM can be very diverse (irregular shape, simple, multi-wall, multi-core, or matrix particle), and there are four types of MPCM (mononuclear, polynuclear, matrix encapsulation, and multi-film).

There are three different methodologies to microencapsulate PCM, based on the mechanism of microparticle formation, and each one is divided in different modes: chemical methodology (suspension polymerization, dispersion polymerization, emulsion polymerization, in situ polymerization, and interfacial polymerization), physico-chemical methodology (coacervation, 
layer-by-layer assembly, sol-gel encapsulation and supercritical $\mathrm{CO}_{2}$-assisted methods), and physico-mechanical methodology (spray-drying, electrostatic encapsulation, and one-step method).

Characterization of MPCM has attracted a lot of attention between researchers and a lot of methods have been used depending on the aim of the analysis and the application considered. This review describes shortly the main techniques used for MPCM characterization at lab scale, including particle size distribution, optical microscopy, SEM, TEM, X-Ray diffraction, wide angle X-ray scattering and low angle laser light scattering, FT-IR, DSC, TGA, and AFM, and some properties analyzed such as flammability, viscosity, density and conductivity measurement, and cycling.

Finally, some applications of MPCM are shortly described. These are cooling systems, active and passive systems in buildings, and textiles and footware.

\section{Acknowledgments}

The work is partially funded by the Spanish government (ENE2011-28269-C03-02 and ENE2011-22722). The authors would like to thank the Catalan Government for the quality accreditation given to their research group GREA (2014 SGR 123) and research group DIOPMA (2014 SGR 1543). The research leading to these results has received funding from the European Union's Seventh Framework Programme (FP7/2007-2013) under grant agreement $n^{\circ}$ PIRSES-GA-2013-610692 (INNOSTORAGE).

\section{References}

[1] Zalba B, Marín JM, Cabeza LF, Mehling H. Review on thermal energy storage with phase change: materials, heat transfer analysis and applications. Appl Therm Eng 2003;23:251-83. doi:10.1016/S1359-4311(02)00192-8.

[2] Pomianowski M, Heiselberg P, Zhang Y. Review of thermal energy storage technologies based on PCM application in buildings. Energy Build 2013;67:56-69. doi:10.1016/j.enbuild.2013.08.006.

[3] Kumar R, Misra M, Kumar R, Gupta D, Khatri P, Tak B, et al. Phase Change Materials: Technology Status and Potential Defence Applications. Def Sci J 2011;61:576-82. doi:10.14429/dsj.61.363.

[4] http://www.scopus.com/ n.d. 
[5] Sánchez P, Sánchez-Fernandez MV, Romero A, Rodríguez JF, Sánchez-Silva L. Development of thermo-regulating textiles using paraffin wax microcapsules. Thermochim Acta 2010;498:16-21. doi:10.1016/j.tca.2009.09.005.

[6] Keyan K, Ramachandran T, Shamugasundaram OL, Balasubramaniam M, RagavendraT. Microencapsulation of PCMs in Textiles: A Review. J Text Apparel, Technol Manag 2012;7:1-10.

[7] Baetens R, Jelle BP, Gustavsen A. Phase change materials for building applications: A state-of-the-art review. Energy Build 2010;42:1361-8.

doi:10.1016/j.enbuild.2010.03.026.

[8] Tyagi VV, Buddhi D. PCM thermal storage in buildings: A state of art. Renew Sustain Energy Rev 2007;11:1146-66. doi:10.1016/j.rser.2005.10.002.

[9] Arce P, Castellón C, Castell A, Cabeza LF. Use of microencapsulated PCM in buildings and the effect of adding awnings. Energy Build 2012;44:88-93.

doi:10.1016/j.enbuild.2011.10.028.

[10] Oró E, Gil A, Miró L, Peiró G, Álvarez S, Cabeza LF. Thermal Energy Storage Implementation Using Phase Change Materials for Solar Cooling and Refrigeration Applications. Energy Procedia 2012;30:947-56. doi:10.1016/j.egypro.2012.11.107.

[11] Gil A, Oró E, Miró L, Peiró G, Ruiz Á, Salmerón JM, et al. Experimental analysis of hydroquinone used as phase change material (PCM) to be applied in solar cooling refrigeration. Int J Refrig 2014;39:95-103. doi:10.1016/j.ijrefrig.2013.05.013.

[12] Lu W, Tassou S a. Characterization and experimental investigation of phase change materials for chilled food refrigerated cabinet applications. Appl Energy 2013;112:137682. doi:10.1016/j.apenergy.2013.01.071.

[13] Oró E, Miró L, Farid MM, Cabeza LF. Thermal analysis of a low temperature storage unit using phase change materials without refrigeration system. Int J Refrig 2012;35:1709-14. doi:doi:10.1016/j.ijrefrig.2012.05.004.

[14] Oró E, De Gracia A, Cabeza LF. Active phase change material package for thermal protection of ice cream containers. Int J Refrig 2013;36:102-9.

doi:doi:10.1016/j.ijrefrig.2012.09.011.

[15] Oró E, Cabeza LF, Farid MM. Experimental and numerical analysis of a chilly bin incorporating phase change material. Appl Therm Eng 2013;58:61-7. doi:doi:10.1016/j.applthermaleng.2013.04.014.

[16] Oró E, Miró L, Barreneche C, Martorell I, Farid MM, Cabeza LF. Corrosion of metal and polymer containers for use in PCM cold storage. Appl Energy 2013;109:449-53. doi:doi:10.1016/j.apenergy.2012.10.049.

[17] Günther E, Schmid T, Mehling H, Hiebler S, Huang L. Subcooling in hexadecane emulsions. Int J Refrig 2010;33:1605-11. doi:10.1016/j.ijrefrig.2010.07.022.

[18] Dutil Y, Rousse D, Lassue S, Zalewski L, Joulin A VJ. Modeling phase change materials behaviour in building applications: selected comments. World Renew. Energy Congr., Sweden: 2011. 
[19] Lin C-C, Yu K-P, Zhao P, Whei-May Lee G. Evaluation of impact factors on VOC emissions and concentrations from wooden flooring based on chamber tests. Build Environ 2009;44:525-33. doi:10.1016/j.buildenv.2008.04.015.

[20] Rozanna D, Salmiah A, Chuah TG, Medyan R, Thomas Choong SY SM. A study on thermal characteristics of phase change material (PCM) in gypsum board for building application. J Oil Palm Res 2005;17:41-6.

[21] Kuznik F, Virgone J, Roux J-J. Energetic efficiency of room wall containing PCM wallboard: A full-scale experimental investigation. Energy Build 2008;40:148-56. doi:10.1016/j.enbuild.2007.01.022.

[22] Feldman D, Banu D, Hawes D, Ghanbari E. Obtaining an energy storing building material by direct incorporation of an organic phase change material in gypsum wallboard. Sol Energy Mater 1991;22:231-42. doi:10.1016/0165-1633(91)90021-C.

[23] Kuznik F, David D, Johannes K, Roux J-J. A review on phase change materials integrated in building walls. Renew Sustain Energy Rev 2011;15:379-91. doi:10.1016/j.rser.2010.08.019.

[24] Castell A, Martorell I, Medrano M, Pérez G, Cabeza LF. Experimental study of using PCM in brick constructive solutions for passive cooling. Energy Build 2010;42:534-40.

[25] Kabbara MJ, Abdallah NB. Experimental Investigation on Phase Change Material based Thermal Energy Storage Unit. Procedia Comput Sci 2013;19:694-701. doi:10.1016/j.procs.2013.06.092.

[26] Cabeza LF, Ibáñez M, Solé C, Roca J, Nogués M. Experimentation with a water tank including a PCM module. Sol Energy Mater Sol Cells 2006;90:1273-82. doi:doi:10.1016/j.solmat.2005.08.002.

[27] Jordan U VK. Realistic domestic hot-water profiles in different time scales. IEA SHC. Task 26Solar combisystems, 2001.

[28] Mehling H, Cabeza LF, Hippeli S, Hiebler S. PCM-module to improve hot water heat stores with stratification. Renew Energy 2003;28:699-711.

[29] Haillot D, Nepveu F, Goetz V, Py X, Benabdelkarim M. High performance storage composite for the enhancement of solar domestic hot water systems. Sol Energy 2012;86:64-77. doi:10.1016/j.solener.2011.09.006.

[30] Pasupathy a., Velraj R, Seeniraj RV. Phase change material-based building architecture for thermal management in residential and commercial establishments. Renew Sustain Energy Rev 2008;12:39-64. doi:10.1016/j.rser.2006.05.010.

[31] Zheng Y, Zhao W, Sabol JC, Tuzla K, Neti S, Oztekin A, et al. Encapsulated phase change materials for energy storage - Characterization by calorimetry. Sol Energy 2013;87:117-26. doi:10.1016/j.solener.2012.10.003.

[32] Pendyala S. Macroencapsulation of Phase Change Materials for Thermal Energy Storage. Univ South Florida Sch Commons 2012.

[33] S B. Microencapsulation: methods and industrial applications. CRC Press, 2006. 
[34] Jamekhorshid A, Sadrameli SM, Farid M. A review of microencapsulation methods of phase change materials (PCMs) as a thermal energy storage (TES) medium. Renew Sustain Energy Rev 2014;31:531-42. doi:10.1016/j.rser.2013.12.033.

[35] Sukhorukov G, Fery a., Möhwald H. Intelligent micro- and nanocapsules. Prog Polym Sci 2005;30:885-97. doi:10.1016/j.progpolymsci.2005.06.008.

[36] Castellón C, Martorell I, Cabeza LF, Fernández AI, Manich AM. Compatibility of plastic with phase change materials (PCM). Int J Energy Res 2011;35:765-71. doi:10.1002/er.1723.

[37] Giro-Paloma J, Roa JJ, Díez-Pascual AM, Rayón E, Flores A, Martínez M, et al. Depthsensing indentation applied to polymers: A comparison between standard methods of analysis in relation to the nature of the materials. Eur Polym J 2013;49:4047-53. doi:10.1016/j.eurpolymj.2013.09.010.

[38] Soares N, Costa JJ, Gaspar a. R, Santos P. Review of passive PCM latent heat thermal energy storage systems towards buildings' energy efficiency. Energy Build 2013;59:82103. doi:10.1016/j.enbuild.2012.12.042.

[39] Tyagi VV, Kaushik SC, Tyagi SK, Akiyama T. Development of phase change materials based microencapsulated technology for buildings: A review. Renew Sustain Energy Rev 2011;15:1373-91. doi:10.1016/j.rser.2010.10.006.

[40] Dutil Y, Rousse D, Lassue S, Zalewski L, Joulin A, Virgone J, et al. Modeling phase change materials behavior in building applications: Comments on material characterization and model validation. Renew Energy 2014;61:132-5. doi:10.1016/j.renene.2012.10.027.

[41] Wang H, Wang JP, Wang X, Li W, Zhang X. Preparation and Properties of Microencapsulated Phase Change Materials Containing Two-Phase Core Materials. Ind Eng Chem Res 2013;52:14706-12. doi:10.1021/ie401055r.

[42] Ma Y, Sun S, Li J, Tang G. Preparation and thermal reliabilities of microencapsulated phase change materials with binary cores and acrylate-based polymer shells. Thermochim Acta 2014;588:38-46. doi:10.1016/j.tca.2014.04.023.

[43] Cabeza LF, Castell a., Barreneche C, de Gracia a., Fernández a. I. Materials used as PCM in thermal energy storage in buildings: A review. Renew Sustain Energy Rev 2011;15:1675-95. doi:10.1016/j.rser.2010.11.018.

[44] Suppes GJ, Goff MJ, Lopes S. Latent heat characteristics of fatty acid derivatives pursuant phase change material applications. Chem Eng Sci 2003;58:1751-63. doi:10.1016/S0009-2509(03)00006-X.

[45] Sharma A, Tyagi VV, Chen CR, Buddhi D. Review on thermal energy storage with phase change materials and applications. Renew Sustain Energy Rev 2009;13:318-45. doi:10.1016/j.rser.2007.10.005.

[46] Das A. Study of Microencapsulation in Dyeing n.d. http://es.slideshare.net/Arkatextile/microencapsulation-in-dyeing. 
[47] Tan FL, Hosseinizadeh SF, Khodadadi JM, Fan L. Experimental and computational study of constrained melting of phase change materials (PCM) inside a spherical capsule. Int J Heat Mass Transf 2009;52:3464-72. doi:10.1016/j.ijheatmasstransfer.2009.02.043.

[48] Zhang GH, Bon SAF, Zhao CY. Synthesis, characterization and thermal properties of novel nanoencapsulated phase change materials for thermal energy storage. Sol Energy 2012;86:1149-54. doi:10.1016/j.solener.2012.01.003.

[49] Wang X, Zhang X, Tao X, Yick K. Structure and thermal stability of microencapsulated phase-change materials. Colloid Polym Sci 2004;282:330-6. doi:10.1007/s00396-0030925-y.

[50] Khudhair AM, Farid MM. A review on energy conservation in building applications with thermal storage by latent heat using phase change materials. Energy Convers Manag 2004;45:263-75. doi:10.1016/S0196-8904(03)00131-6.

[51] Qiu X, Lu L, Wang J, Tang G, Song G. Preparation and characterization of microencapsulated n-octadecane as phase change material with different n-butyl methacrylate-based copolymer shells. Sol Energy Mater Sol Cells 2014;128:102-11. doi:10.1016/j.solmat.2014.05.020.

[52] Alkan C, Sarı A, Karaipekli A, Uzun O. Preparation, characterization, and thermal properties of microencapsulated phase change material for thermal energy storage. Sol Energy Mater Sol Cells 2009;93:143-7. doi:10.1016/j.solmat.2008.09.009.

[53] Qiu X, Li W, Song G, Chu X, Tang G. Microencapsulated n-octadecane with different methylmethacrylate-based copolymer shells as phase change materials for thermal energy storage. Energy 2012;46:188-99. doi:10.1016/j.energy.2012.08.037.

[54] Ma Y, Chu X, Tang G, Yao Y. Synthesis and thermal properties of acrylate-based polymer shell microcapsules with binary core as phase change materials. Mater Lett 2013;91:133-5. doi:10.1016/j.matlet.2012.09.084.

[55] Qiu X, Song G, Chu X, Li X, Tang G. Microencapsulated n-alkane with p(n-butyl methacrylate-co-methacrylic acid) shell as phase change materials for thermal energy storage. Sol Energy 2013;91:212-20. doi:10.1016/j.solener.2013.01.022.

[56] Sarı A, Alkan C, Karaipekli A, Uzun O. Microencapsulated n-octacosane as phase change material for thermal energy storage. Sol Energy 2009;83:1757-63. doi:10.1016/j.solener.2009.05.008.

[57] Alkan C, Sarı A, Karaipekli A. Preparation, thermal properties and thermal reliability of microencapsulated n-eicosane as novel phase change material for thermal energy storage. Energy Convers Manag 2011;52:687-92. doi:10.1016/j.enconman.2010.07.047.

[58] Alay S, Alkan C, Göde F. Synthesis and characterization of poly(methyl methacrylate)/n-hexadecane microcapsules using different cross-linkers and their application to some fabrics. Thermochim Acta 2011;518:1-8. doi:10.1016/j.tca.2011.01.014.

[59] Wang Y, Shi H, Xia TD, Zhang T, Feng HX. Fabrication and performances of microencapsulated paraffin composites with polymethylmethacrylate shell based on ultraviolet irradiation-initiated. Mater Chem Phys 2012;135:181-7. doi:10.1016/j.matchemphys.2012.04.050. 
[60] Taguchi Y, Yokoyama H, Kado H, Tanaka M. Preparation of PCM microcapsules by using oil absorbable polymer particles. Colloids Surfaces A Physicochem Eng Asp 2007;301:41-7. doi:10.1016/j.colsurfa.2006.12.019.

[61] Tzvetkov G, Graf B, Wiegner R, Raabe J, Quitmann C, Fink R. Soft X-ray spectromicroscopy of phase-change microcapsules. Micron 2008;39:275-9. doi:10.1016/j.micron.2007.04.002.

[62] Alkan C, Sari A. Fatty acid/poly(methyl methacrylate) (PMMA) blends as form-stable phase change materials for latent heat thermal energy storage. Sol Energy 2008;82:11824. doi:10.1016/j.solener.2007.07.001.

[63] Giro-Paloma J, Oncins G, Barreneche C, Martínez M, Fernández AI, Cabeza LF. Physico-chemical and mechanical properties of microencapsulated phase change material. Appl Energy 2013;109:441-8. doi:10.1016/j.apenergy.2012.11.007.

[64] Su J-F, Wang X-Y, Dong H. Influence of temperature on the deformation behaviors of melamine-formaldehyde microcapsules containing phase change material. Mater Lett 2012;84:158-61. doi:10.1016/j.matlet.2012.06.074.

[65] Palanikkumaran M, Gupta KK, Agrawal AK, Jassal M. Effect of emulsion preparation method on microencapsulation of $\mathrm{n}$-octadecane using melamine-formaldehyde prepolymers. Indian J Fibre Text Res 2010;35:101-6.

[66] Zhao CY, Zhang GH. Review on microencapsulated phase change materials (MEPCMs): Fabrication, characterization and applications. Renew Sustain Energy Rev 2011;15:3813-32. doi:10.1016/j.rser.2011.07.019.

[67] Sánchez-Silva L, Rodríguez JF, Romero A, Borreguero AM, Carmona M, Sánchez P. Microencapsulation of PCMs with a styrene-methyl methacrylate copolymer shell by suspension-like polymerisation. Chem Eng J 2010;157:216-22.

doi:10.1016/j.cej.2009.12.013.

[68] Sánchez L, Sánchez P, de Lucas A, Carmona M, Rodríguez JF. Microencapsulation of PCMs with a polystyrene shell. Colloid Polym Sci 2007;285:1377-85. doi:10.1007/s00396-007-1696-7.

[69] Sánchez L, Sánchez P, Carmona M, de Lucas A, Rodríguez JF. Influence of operation conditions on the microencapsulation of PCMs by means of suspension-like polymerization. Colloid Polym Sci 2008;286:1019-27. doi:10.1007/s00396-008-1864-4.

[70] Borreguero AM, Carmona M, Sanchez ML, Valverde JL, Rodriguez JF. Improvement of the thermal behaviour of gypsum blocks by the incorporation of microcapsules containing PCMS obtained by suspension polymerization with an optimal core/coating mass ratio. Appl Therm Eng 2010;30:1164-9. doi:10.1016/j.applthermaleng.2010.01.032.

[71] Wang Y, Xia TD, Feng HX, Zhang H. Stearic acid/polymethylmethacrylate composite as form-stable phase change materials for latent heat thermal energy storage. Renew Energy 2011;36:1814-20. doi:10.1016/j.renene.2010.12.022.

[72] Kim OH, Lee K, Kim K, Lee BH, Choe S. Effect of PVA in dispersion polymerization of MMA. Polymer (Guildf) 2006;47:1953-9. doi:10.1016/j.polymer.2006.01.025. 
[73] Kawaguchi S. Dispersion Polymerization 2005:299-328. doi:10.1007/b100118.

[74] Sarı A, Alkan C, Karaipekli A. Preparation, characterization and thermal properties of PMMA/n-heptadecane microcapsules as novel solid-liquid microPCM for thermal energy storage. Appl Energy 2010;87:1529-34. doi:10.1016/j.apenergy.2009.10.011.

[75] Mollidain S. M.Pharmacy (pharmaceutical technology). SHIFT- II n.d. http://www.slideshare.net/mollidain/microencapsulation-by-sandeep.

[76] Choi Y, Lee JG, Kim JH, Yang H. Preparation of microcapsules containing phase change materials as heat transfer media by in-situ polymerization. J Ind Eng Chem 2001.

[77] Jyothi NVN, Prasanna PM, Sakarkar SN, Prabha KS, Ramaiah PS, Srawan GY. Microencapsulation techniques, factors influencing encapsulation efficiency. J Microencapsul 2010;27:187-97. doi:10.3109/02652040903131301.

[78] Sumiga B, Knez E, Vrtačnik M, Ferk-Savec V, Starešinič M, Boh B. Production of Melamine-Formaldehyde PCM Microcapsules with Ammonia Scavenger used for Residual Formaldehyde Reduction. Acta Chim Slov 2011;58:14-25.

[79] Boh B, Knez E, Staresinic M. Microencapsulation of higher hydrocarbon phase change materials by in situ polymerization. J Microencapsul 2005;22:715-35. doi:10.1080/02652040500162139.

[80] Boh B, Šumiga B. Microencapsulation technology and its applications in building construction materials. RMZ- Mater Geoenvironment 2008;55:329-44.

[81] Yang R, Xu H, Zhang Y. Preparation, physical property and thermal physical property of phase change microcapsule slurry and phase change emulsion. Sol Energy Mater Sol Cells 2003;80:405-16. doi:10.1016/j.solmat.2003.08.005.

[82] Yang R, Zhang Y, Wang X, Zhang Y, Zhang Q. Preparation of n-tetradecane-containing microcapsules with different shell materials by phase separation method. Sol Energy Mater Sol Cells 2009;93:1817-22. doi:10.1016/j.solmat.2009.06.019.

[83] Fang G, Li H, Yang F, Liu X, Wu S. Preparation and characterization of nanoencapsulated n-tetradecane as phase change material for thermal energy storage. Chem Eng J 2009;153:217-21. doi:10.1016/j.cej.2009.06.019.

[84] Chen Z, Cao L, Fang G, Shan F. Synthesis and Characterization of Microencapsulated Paraffin Microcapsules as Shape-Stabilized Thermal Energy Storage Materials. Nanoscale Microscale Thermophys Eng 2013;17:112-23. doi:10.1080/15567265.2012.761305.

[85] Song XQ, Li YX, Wang JW. Preparation and Characterization of Hexadecane Microcapsule Phase Change Materials by In Situ Polymerization. Adv Mater Res 2013;815:367-70. doi:10.4028/www.scientific.net/AMR.815.367.

[86] Pascu O, Garcia Valls R, Giamberini M. Interfacial polymerization of an epoxy resin and carboxylic acids for the synthesis of microcapsules. Polym Int 2008;57:995-1006. doi:10.1002/pi.2438. 
[87] Liang C, Lingling X, Hongbo S, Zhibin Z. Microencapsulation of butyl stearate as a phase change material by interfacial polycondensation in a polyurea system. Energy Convers Manag 2009;50:723-9. doi:10.1016/j.enconman.2008.09.044.

[88] Li B, Liu T, Hu L, Wang Y, Gao L. Fabrication and Properties of Microencapsulated Paraffin@SiO 2 Phase Change Composite for Thermal Energy Storage. ACS Sustain Chem Eng 2013;1:374-80. doi:10.1021/sc300082m.

[89] Nagavarma BVN, Yadav HKS, Ayaz a., Vasudha LS, Shivakumar HG. Different techniques for preparation of polymeric nanoparticles- A review. Asian J Pharm Clin Res 2012;5:16-23.

[90] Shivakumar. Microencapsulation. B. pharmacy. kottam institute of pharmacy, A.P n.d.

[91] Özonur Y, Mazman M, Paksoy HÖ, Evliya H. Microencapsulation of coco fatty acid mixture for thermal energy storage with phase change material. Int J Energy Res 2006;30:741-9. doi:10.1002/er.1177.

[92] Fang G, Li H, Liu X. Preparation and properties of lauric acid/silicon dioxide composites as form-stable phase change materials for thermal energy storage. Mater Chem Phys 2010;122:533-6. doi:10.1016/j.matchemphys.2010.03.042.

[93] Li H, Fang G, Liu X. Synthesis of shape-stabilized paraffin/silicon dioxide composites as phase change material for thermal energy storage. J Mater Sci 2009;45:1672-6. doi:10.1007/s10853-009-4146-8.

[94] Tang B, Qiu M, Zhang S. Thermal conductivity enhancement of PEG/SiO2 composite PCM by in situ Cu doping. Sol Energy Mater Sol Cells 2012;105:242-8. doi:10.1016/j.solmat.2012.06.012.

[95] Ghosh SK. Functional Coatings and Microencapsulation: A General Perspective. Funct Coat 2006.

[96] Wu H-T, Yang M-W. Precipitation kinetics of PMMA sub-micrometric particles with a supercritical assisted-atomization process. J Supercrit Fluids 2011;59:98-107. doi:10.1016/j.supflu.2011.08.001.

[97] Haldorai Y, Shim J-J, Lim KT. Synthesis of polymer-inorganic filler nanocomposites in supercritical CO2. J Supercrit Fluids 2012;71:45-63. doi:10.1016/j.supflu.2012.07.007.

[98] Borreguero a. M, Valverde JL, Rodríguez JF, Barber a. H, Cubillo JJ, Carmona M. Synthesis and characterization of microcapsules containing Rubitherm®RT27 obtained by spray drying. Chem Eng J 2011;166:384-90. doi:10.1016/j.cej.2010.10.055.

[99] Hawlader MNA, Uddin MS, Khin MM. Microencapsulated PCM thermal-energy storage system. Appl Energy 2003;74:195-202. doi:10.1016/S0306-2619(02)00146-0.

[100] Fei B, Lu H, Qi K, Shi H, Liu T, Li X, et al. Multi-functional microcapsules produced by aerosol reaction. J Aerosol Sci 2008;39:1089-98. doi:10.1016/j.jaerosci.2008.07.007.

[101] De Windt L, Dabo D, Lidelöw S, Badreddine R, Lagerkvist A. MSWI bottom ash used as basement at two pilot-scale roads: comparison of leachate chemistry and reactive transport modeling. Waste Manag 2011;31:267-80. doi:10.1016/j.wasman.2010.06.002. 
[102] Jin Y, Lee W, Musina Z, Ding Y. A one-step method for producing microencapsulated phase change materials. Particuology 2010;8:588-90. doi:10.1016/j.partic.2010.07.009.

[103] Youssef Z, Delahaye A, Huang L, Trinquet F, Fournaison L, Pollerberg C, et al. State of the art on phase change material slurries. Energy Convers Manag 2013;65:120-32. doi:10.1016/j.enconman.2012.07.004.

[104] Zhang P, Qiu ZZ, He M. Review on Microencapsulated Phase Change Materials (MPCM) Slurries: Materials, Rheological Behavior and Applications. Adv. Mater. Res., vol. 953-954, 2014, p. 1109-12. doi:10.4028/www.scientific.net/AMR.953-954.1109.

[105] Zhang GH, Zhao C-Y. Thermal and rheological properties of microencapsulated phase change materials. Renew Energy 2011;36:2959-66.

doi:doi:10.1016/j.renene.2011.04.002.

[106] Dry powder mixes comprising Phase change Materials. Patent US 5370814, n.d.

[107] Chen Z, Fang G. Preparation and heat transfer characteristics of microencapsulated phase change material slurry: A review. Renew Sustain Energy Rev 2011;15:4624-32. doi:10.1016/j.rser.2011.07.090.

[108] Baronetto S, G S, F G, M P. Numerical Model of a Slurry PCM-Based Solar Thermal Collector. Proc. 8th Int. Symp. Heating, Vent. Air Cond. Lect. Notes Electr. Eng., 2014, p. 13-20. doi:10.1007/978-3-642-39578-9_2.

[109] Knodel BD, France DM, Choi US, Wambsganss MW. Heat transfer and pressure drop in ice-water slurries. Appl Therm Eng 2000;20:671-85. doi:10.1016/S13594311(99)00046-0.

[110] Stamatiou E, Kawaji M. Thermal and flow behavior of ice slurries in a vertical rectangular channel. Part I: Local distribution measurements in adiabatic flow. Int J Heat Mass Transf 2005;48:3527-43. doi:10.1016/j.jiheatmasstransfer.2005.03.020.

[111] Inaba H, Zhang Y, Horibe A, Haruki N. Numerical simulation of natural convection of latent heat phase-change-material microcapsulate slurry packed in a horizontal rectangular enclosure heated from below and cooled from above. Heat Mass Transf 2007;43:459-70. doi:10.1007/s00231-006-0121-y.

[112] Sarı A, Biçer A, Karaipekli A, Alkan C, Karadag A. Synthesis, thermal energy storage properties and thermal reliability of some fatty acid esters with glycerol as novel solidliquid phase change materials. Sol Energy Mater Sol Cells 2010;94:1711-5. doi:10.1016/j.solmat.2010.05.033.

[113] Lu W, Tassou SA. Experimental study of the thermal characteristics of phase change slurries for active cooling. Appl Energy 2012;91:366-74. doi:10.1016/j.apenergy.2011.10.004.

[114] Chen L, Wang T, Zhao Y, Zhang X-R. Characterization of thermal and hydrodynamic properties for microencapsulated phase change slurry (MPCS). Energy Convers Manag 2014;79:317-33. doi:10.1016/j.enconman.2013.12.026. 
[115] Zhang P, Ma ZW. An overview of fundamental studies and applications of phase change material slurries to secondary loop refrigeration and air conditioning systems. Renew Sustain Energy Rev 2012;16:5021-58. doi:10.1016/j.rser.2012.03.059.

[116] Al-Abidi A a., Bin Mat S, Sopian K, Sulaiman MY, Lim CH, Th A. Review of thermal energy storage for air conditioning systems. Renew Sustain Energy Rev 2012;16:580219. doi:10.1016/j.rser.2012.05.030.

[117] Domínguez M, García C. Aprovechamiento de los Materiales de Cambio de Fase (PCM) en la Climatización. Inf Tecnológic 2009;20:107-15.

[118] Delgado M, Lázaro A, Mazo J, Zalba B. Review on phase change material emulsions and microencapsulated phase change material slurries: Materials, heat transfer studies and applications. Renew Sustain Energy Rev 2012;16:253-73. doi:10.1016/j.rser.2011.07.152.

[119] Alvarado JL, Marsh C, Sohn C, Phetteplace G, Newell T. Thermal performance of microencapsulated phase change material slurry in turbulent flow under constant heat flux. Int J Heat Mass Transf 2007;50:1938-52. doi:10.1016/j.ijheatmasstransfer.2006.09.026.

[120] Huang L, Doetsch C, Pollerberg C. Low temperature paraffin phase change emulsions. Int J Refrig 2010;33:1583-9. doi:10.1016/j.ijrefrig.2010.05.016.

[121] Zhang P, Ma ZW, Wang RZ. An overview of phase change material slurries: MPCS and CHS. Renew Sustain Energy Rev 2010;14:598-614. doi:10.1016/j.rser.2009.08.015.

[122] Al-Abidi AA, Bin Mat S, Sopian K, Sulaiman MY, Lim CH, Th A. Review of thermal energy storage for air conditioning systems. Renew Sustain Energy Rev 2012;16:580219. doi:10.1016/j.rser.2012.05.030.

[123] Huang MJ, Eames PC, McCormack S, Griffiths P, Hewitt NJ. Microencapsulated phase change slurries for thermal energy storage in a residential solar energy system. Renew Energy 2011;36:2932-9. doi:10.1016/j.renene.2011.04.004.

[124] Augood PC, Newborough M, Highgate DJ. Thermal behaviour of phase-change slurries incorporating hydrated hydrophilic polymeric particles. Exp Therm Fluid Sci 2001;25:457-68. doi:10.1016/S0894-1777(01)00099-1.

[125] Salunkhe PB, Shembekar PS. A review on effect of phase change material encapsulation on the thermal performance of a system. Renew Sustain Energy Rev 2012;16:5603-16. doi:10.1016/j.rser.2012.05.037.

[126] Zhang S, Niu J. Experimental investigation of effects of supercooling on microencapsulated phase-change material (MPCM) slurry thermal storage capacities. Sol Energy Mater Sol Cells 2010;94:1038-48. doi:10.1016/j.solmat.2010.02.022.

[127] Zeng R, Wang X, Chen B, Zhang Y, Niu J, Wang X, et al. Heat transfer characteristics of microencapsulated phase change material slurry in laminar flow under constant heat flux. Appl Energy 2009;86:2661-70. doi:10.1016/j.apenergy.2009.04.025.

[128] Huang L, Günther E, Doetsch C, Mehling H. Subcooling in PCM emulsions-Part 1: Experimental. Thermochim Acta 2010;509:93-9. doi:10.1016/j.tca.2010.06.006. 
[129] Günther E, Huang L, Mehling H, Dötsch C. Subcooling in PCM emulsions - Part 2: Interpretation in terms of nucleation theory. Thermochim Acta 2011;522:199-204. doi:10.1016/j.tca.2011.04.027.

[130] De Boer GBJ, de Weerd C, Thoenes D, Goossens HWJ. Laser Diffraction Spectrometry: Fraunhofer Diffraction Versus Mie Scattering. Part Part Syst Charact 1987;4:14-9. doi:10.1002/ppsc.19870040104.

[131] Yu F, Chen Z-H, Zeng X-R. Preparation, characterization, and thermal properties of microPCMs containing n-dodecanol by using different types of styrene-maleic anhydride as emulsifier. Colloid Polym Sci 2009;287:549-60. doi:10.1007/s00396-009-2001-8.

[132] Bayés-García L, Ventolà L, Cordobilla R, Benages R, Calvet T, Cuevas-Diarte M a. Phase Change Materials (PCM) microcapsules with different shell compositions: Preparation, characterization and thermal stability. Sol Energy Mater Sol Cells 2010;94:1235-40. doi:10.1016/j.solmat.2010.03.014.

[133] Bajāre D, Kazjonovs J, Korjakins A, Merijs-Meri R. Development of Cement and Lime Based Plaster with Microencapsulated Phase Change Materials (PCM). 12th Int. Conf. Energy Storage, 2012, p. 1-7.

[134] Pan L, Tao Q, Zhang S, Wang S, Zhang J, Wang S, et al. Preparation, characterization and thermal properties of micro-encapsulated phase change materials. Sol Energy Mater Sol Cells 2012;98:66-70. doi:10.1016/j.solmat.2011.09.020.

[135] Fang G, Chen Z, Li H. Synthesis and properties of microencapsulated paraffin composites with $\mathrm{SiO} 2$ shell as thermal energy storage materials. Chem Eng J 2010;163:154-9. doi:10.1016/j.cej.2010.07.054.

[136] Fang Y, Kuang S, Gao X, Zhang Z. Preparation and characterization of novel nanoencapsulated phase change materials. Energy Convers Manag 2008;49:3704-7. doi:10.1016/j.enconman.2008.06.027.

[137] Zhang H, Wang X. Fabrication and performances of microencapsulated phase change materials based on n-octadecane core and resorcinol-modified melamine-formaldehyde shell. Colloids Surfaces A Physicochem Eng Asp 2009;332:129-38. doi:10.1016/j.colsurfa.2008.09.013.

[138] Alkan C. Enthalpy of melting and solidification of sulfonated paraffins as phase change materials for thermal energy storage. Thermochim Acta 2006;451:126-30. doi:10.1016/j.tca.2006.09.010.

[139] Zhang T, Wang Y, Shi H, Yang W. Fabrication and performances of new kind microencapsulated phase change material based on stearic acid core and polycarbonate shell. Energy Convers Manag 2012;64:1-7. doi:10.1016/j.enconman.2012.04.011.

[140] Pomianowski M, Heiselberg P, Jensen RL, Cheng R, Zhang Y. A new experimental method to determine specific heat capacity of inhomogeneous concrete material with incorporated microencapsulated-PCM. Cem Concr Res 2014;55:22-34. doi:10.1016/j.cemconres.2013.09.012.

[141] Ostrý M, Pøikryl R, Charvát P, Mlcoch T, Bakajová B. Laboratory assessment of microencapsulated phase-change materials. Mater Technol 2012;46:531-4. 
[142] Zhang H, Sun S, Wang X, Wu D. Fabrication of microencapsulated phase change materials based on n-octadecane core and silica shell through interfacial polycondensation. Colloids Surfaces A Physicochem Eng Asp 2011;389:104-17. doi:10.1016/j.colsurfa.2011.08.043.

[143] Giro-Paloma J, Barreneche C, Delgado M, Martínez M, Fernández AI, Cabeza LF. Physicochemical and thermal study of a MPCM of PMMA shell and paraffin wax as a core. Energy Procedia, vol. 48, 2014, p. 347-54. doi:10.1016/j.egypro.2014.02.040.

[144] Huang H, Haghighat F. Building materials VOC emissions-a systematic parametric study. Build Environ 2003;38:995-1005. doi:10.1016/S0360-1323(03)00062-3.

[145] Kim S, Choi Y-K, Park K-W, Kim JT. Test methods and reduction of organic pollutant compound emissions from wood-based building and furniture materials. Bioresour Technol 2010;101:6562-8. doi:10.1016/j.biortech.2010.03.059.

[146] Jia C, Batterman S, Godwin C. VOCs in industrial, urban and suburban neighborhoods, Part 1: Indoor and outdoor concentrations, variation, and risk drivers. Atmos Environ 2008;42:2083-100. doi:10.1016/j.atmosenv.2007.11.055.

[147] Jia C, Batterman S, Godwin C, Charles S, Chin J-Y. Sources and migration of volatile organic compounds in mixed-use buildings. Indoor Air 2010;20:357-69. doi:10.1111/j.1600-0668.2010.00643.x.

[148] Schlink U, Rehwagen M, Damm M, Richter M, Borte M, Herbarth O. Seasonal cycle of indoor-VOCs: comparison of apartments and cities. Atmos Environ 2004;38:1181-90. doi:10.1016/j.atmosenv.2003.11.003.

[149] Zhang Y, Xu Y. Characteristics and correlations of VOC emissions from building materials. Int J Heat Mass Transf 2003;46:4877-83. doi:10.1016/S0017-9310(03)003521 .

[150] Lee C-S, Haghighat F, Ghaly WS. A study on VOC source and sink behavior in porous building materials - analytical model development and assessment. Indoor Air 2005;15:183-96. doi:10.1111/j.1600-0668.2005.00335.x.

[151] Lee C-S, Haghighat F, Ghaly W. Conjugate Mass Transfer Modeling for VOC Source and Sink Behavior of Porous Building Materials: When to Apply It? J Build Phys 2006;30:91-111. doi:10.1177/1744259106067683.

[152] Ayoko GA. Volatile Organic Compounds in Indoor Environments. 2004.

[153] Magee RJ, Bodalal A, Biesenthal TA, Lusztyk E, Brouzes M, Shaw CY. Prediction of VOC concentration profiles in a newly constructed house using samll chamber data and an IAQ simulation program. 9th Int. Conf. IAQ Clim., 2002, p. 298-303.

[154] Berrios IT, Zhang J, Guo B, Smith J, Zhang Z. Volatile organic compounds (VOCS) emissions from sources in a partitioned office environment and their impact on IAQ. 10th Int. Conf. indoor air Qual. Clim. (indoor air), 2005.

[155] Molhave L, Clausen G, Berglund B, Ceaurriz JDE, Kettrup A, Lindvall T. Total Volatile Organic Compounds ( TVOC ) in Indoor Air Quality Investigations ". Indoor Air 1997;7:225-40. 
[156] Filella I, Peñuelas J. Daily, weekly, and seasonal time courses of VOC concentrations in a semi-urban area near Barcelona. Atmos Environ 2006;40:7752-69.

doi:10.1016/j.atmosenv.2006.08.002.

[157] Jia C, Batterman SA, Relyea GE. Variability of indoor and outdoor VOC measurements: an analysis using variance components. Environ Pollut 2012;169:152-9. doi:10.1016/j.envpol.2011.09.024.

[158] Haghighat F, Huang H. Integrated IAQ model for prediction of VOC emissions from building material. Build Environ 2003;38:1007-17. doi:10.1016/S0360-1323(03)000647.

[159] Huang H, Haghighat F, Blondeau P. Volatile organic compound (VOC) adsorption on material: influence of gas phase concentration, relative humidity and VOC type. Indoor Air 2006;16:236-47. doi:10.1111/j.1600-0668.2005.00421.x.

[160] Missia DA, Demetriou E, Michael N, Tolis EI, Bartzis JG. Indoor exposure from building materials: A field study. Atmos Environ 2010;44:4388-95.

doi:10.1016/j.atmosenv.2010.07.049.

[161] Jalaludin J, Nordiyana MS., Suhaimi NF. Exposure to indoor air pollutants (formaldehyde, VOCs, ultrafine particles) and respiratory health symptoms among office workers in old and new buildings in Universiti Putra Malaysia. Int J Appl Nat Sci 2014;3:69-80.

[162] Cabeza LF, Castellón C, Nogués M, Medrano M, Leppers R, Zubillaga O. Use of microencapsulated PCM in concrete walls for energy savings. Energy Build 2007;39:113-9. doi:10.1016/j.enbuild.2006.03.030.

[163] Lee SH, Yoon SJ, Kim YG, Choi YC, Kim JH, Lee JG. Development of building materials by using micro-encapsulated phase change material. Korean J Chem Eng 2007;24:332-5. doi:10.1007/s11814-007-5054-8.

[164] Zhou G, Zhang Y, Wang X, Lin K, Xiao W. An assessment of mixed type PCM-gypsum and shape-stabilized PCM plates in a building for passive solar heating. Sol Energy 2007;81:1351-60. doi:10.1016/j.solener.2007.01.014.

[165] Safari V, Barreneche C, Castell A, Basatni A, Navarro L, Cabeza L, et al. Volatile organic emission from PCM building materials. Innostock 2012 - 12th Int. Conf. Energy Storage, 2012.

[166] Hunger M, Entrop AG, Mandilaras I, Brouwers HJH, Founti M. The behavior of selfcompacting concrete containing micro-encapsulated Phase Change Materials. Cem Concr Compos 2009;31:731-43. doi:10.1016/j.cemconcomp.2009.08.002.

[167] Shin SH, Jo WK. Volatile organic compound concentrations, emission rates, and source apportionment in newly-built apartments at pre-occupancy stage. Chemosphere 2012;89:569-78. doi:10.1016/j.chemosphere.2012.05.054.

[168] Cai Y, Wei Q, Huang F, Lin S, Chen F, Gao W. Thermal stability, latent heat and flame retardant properties of the thermal energy storage phase change materials based on paraffin/high density polyethylene composites. Renew Energy 2009;34:2117-23. doi:10.1016/j.renene.2009.01.017. 
[169] JC M. A treatise on electricity and magnetism. New York: 1954.

[170] Wang X, Niu J. Heat Transfer of Microencapsulated PCM Slurry Flow in a Circular Tube 2008;54. doi:10.1002/aic.

[171] Silakhori M, Naghavi M, Metselaar H, Mahlia T, Fauzi H, Mehrali M. Accelerated Thermal Cycling Test of Microencapsulated Paraffin Wax/Polyaniline Made by Simple Preparation Method for Solar Thermal Energy Storage. Materials (Basel) 2013;6:160820. doi:10.3390/ma6051608.

[172] Hawlader MN a., Uddin MS, Zhu HJ. Encapsulated phase change materials for thermal energy storage: Experiments and simulation. Int J Energy Res 2002;26:159-71. doi:10.1002/er.773.

[173] Sharma SD, Buddhi D, Sawhney RL. Accelerated thermal cycle test of latent heatstorage materials. Sol Energy 1999;66:483-90. doi:10.1016/S0038-092X(99)00045-6.

[174] Fortuniak W, Slomkowski S, Chojnowski J, Kurjata J, Tracz A, Mizerska U. Synthesis of a paraffin phase change material microencapsulated in a siloxane polymer. Colloid Polym Sci 2013;291:725-33. doi:10.1007/s00396-012-2782-z.

[175] Griffiths PW, Eames PC. Performance of chilled ceiling panels using phase change material slurries as the heat transport medium. Appl Therm Eng 2007;27:1756-60. doi:10.1016/j.applthermaleng.2006.07.009.

[176] Pons O, Aguado A, Fernández AI, Cabeza LF, Chimenos JM. Review of the use of phase change materials (PCMs) in buildings with reinforced concrete structures. Mater Construcción 2014;64:e031. doi:10.3989/mc.2014.05613.

[177] Norvell C, Sailor DJ, Dusicka P. The Effect of Microencapsulated Phase-Change Material on the Compressive Strength of Structural Concrete. J Green Build 2013;8:11624. doi:http://dx.doi.org/10.3992/jgb.8.3.116.

[178] Hunger M, Entrop a. G, Mandilaras I, Brouwers HJH, Founti M. The behavior of selfcompacting concrete containing micro-encapsulated Phase Change Materials. Cem Concr Compos 2009;31:731-43. doi:10.1016/j.cemconcomp.2009.08.002.

[179] Ling T-C, Poon C-S. Use of phase change materials for thermal energy storage in concrete: An overview. Constr Build Mater 2013;46:55-62. doi:10.1016/j.conbuildmat.2013.04.031.

[180] Thiele AM, Sant G, Pilon L. Diurnal thermal analysis of microencapsulated PCMconcrete composite walls. Energy Convers Manag 2015;93:215-27. doi:10.1016/j.enconman.2014.12.078.

[181] Cheng R, Pomianowski M, Wang X, Heiselberg P, Zhang Y. A new method to determine thermophysical properties of PCM-concrete brick. Appl Energy 2013;112:988-98. doi:10.1016/j.apenergy.2013.01.046.

[182] Schossig P, Henning H-M, Gschwander S, Haussmann T. Micro-encapsulated phasechange materials integrated into construction materials. Sol Energy Mater Sol Cells 2005;89:297-306. doi:doi:10.1016/j.solmat.2005.01.017. 
[183] Borreguero AM, Luz Sánchez M, Valverde JL, Carmona M, Rodríguez JF. Thermal testing and numerical simulation of gypsum wallboards incorporated with different PCMs content. Appl Energy 2011;88:930-7. doi:10.1016/j.apenergy.2010.08.014.

[184] Barreneche C, de Gracia A, Serrano S, Elena Navarro M, Borreguero AM, Inés Fernández a., et al. Comparison of three different devices available in Spain to test thermal properties of building materials including phase change materials. Appl Energy 2013;109:421-7. doi:10.1016/j.apenergy.2013.02.061.

[185] Borreguero AM, Garrido I, Valverde JL, Rodríguez JF, Carmona M. Development of smart gypsum composites by incorporating thermoregulating microcapsules. Energy Build 2014;76:631-9. doi:10.1016/j.enbuild.2014.03.005.

[186] Toppi T, Mazzarella L. Gypsum based composite materials with micro-encapsulated PCM: Experimental correlations for thermal properties estimation on the basis of the composition. Energy Build 2013;57:227-36. doi:10.1016/j.enbuild.2012.11.009.

[187] Castellón C, Castell A, Medrano M, Martorell I, Cabeza LF. Experimental study of PCM inclusion in different building envelopes. J Sol Energy Eng 2009;131:410061-6. doi:10.1115/1.3197843.

[188] Castellón C, Medrano M, Roca J, Cabeza LF, Navarro ME, Fernández AI, et al. Effect of microencapsulated phase change material in sandwich panels. Renew Energy 2010;35:2370-4. doi:10.1016/j.renene.2010.03.030.

[189] Borreguero AM, Valverde JL, Peijs T, Rodríguez JF, Carmona M. Characterization of rigid polyurethane foams containing microencapsulated Rubitherm® RT27. Part I. J Mater Sci 2010;45:4462-9. doi:10.1007/s10853-010-4529-x.

[190] Borreguero AM, Rodríguez JF, Valverde JL, Arevalo R, Peijs T, Carmona M. Characterization of rigid polyurethane foams containing microencapsulated Rubitherm ${ }^{\circledR}$ RT27: catalyst effect. Part II. J Mater Sci 2010;46:347-56. doi:10.1007/s10853-0104824-6.

[191] Borreguero AM, Rodríguez JF, Valverde JL, Peijs T, Carmona M. Characterization of rigid polyurethane foams containing microencapsulted phase change materials: Microcapsules type effect. J Appl Polym Sci 2013;128:582-90. doi:10.1002/app.38226.

[192] Shim H, McCullough EA, Jones BW. Using Phase Change Materials in Clothing. Text Res J 2001;71:495-502. doi:10.1177/004051750107100605.

[193] Ying B, Kwok Y, Li Y, Zhu Q, Yeung C. Assessing the performance of textiles incorporating phase change materials. Polym Test 2004;23:541-9. doi:10.1016/j.polymertesting.2003.11.002.

[194] Shin Y, Yoo D-I, Son K. Development of thermoregulating textile materials with microencapsulated phase change materials (PCM). II. Preparation and application of PCM microcapsules. J Appl Polym Sci 2005;96:2005-10. doi:10.1002/app.21438.

[195] Sun YC, Cheng ZH. Heat Buffering Property of Phase Change Materials in Textiles. Key Eng. Mater., vol. 474-476, 2011, p. 1024-8. doi:10.4028/www.scientific.net/KEM.474-476.1024. 
[196] Borreguero AM, Talavera B, Rodriguez JF, Valverde JL, Gonzalez JL, Carmona M. Enhancing the thermal comfort of fabrics for the footwear industry. Text Res J 2013;83:1754-63. doi:10.1177/0040517513481872. 